\title{
ECONOMIC GROWTH IN A CROSS-SECTION OF CITIES
}

\author{
Edward L. Glaeser \\ José A. Scheinkman \\ Andrei Shleifer
}

Working Paper No. 5013

\section{NATIONAL BUREAU OF ECONOMIC RESEARCH 1050 Massachusetts Avenue \\ Cambridge, MA 02138 \\ February 1995}

The title is partially borrowed from Barro (1991). Participants in the Harvard Urban Workshop, the Harvard Growth Workshop, the NBER Summer Institute and one anonymous referee provided helpful comments. David Mare and Melissa McSherry provided excellent research assistance, and the NSF provided research support. This paper is part of NBER's research program in Growth. Any opinions expressed are those of the authors and not those of the National Bureau of Economic Research.

() 1995 by Edward L. Glaeser, José A. Scheinkman and Andrei Shleifer. All rights reserved. Short sections of text, not to exceed two paragraphs, may be quoted without explicit permission provided that full credit, including $\odot$ notice, is given to the source. 


\title{
ECONOMIC GROWTH IN A CROSS-SECTION OF CITIES
}

\begin{abstract}
We examine the relationship between urban characteristics in 1960 and urban growth (income and population) between 1960 and 1990. Our major findings are that income and population growth move together and both types of growth are (1) positively related to initial schooling, (2) negatively related to initial unemployment and (3) negatively related to the share of employment initially in manufacturing. These results are qualitatively unchanged if we examine cities (a smaller political unit) or SMSAs (a larger "economic" unit). We also find that racial composition and segregation are basically uncorrelated with urban growth across all cities, but that in communities with large nonwhite communities segregation is positively correlated with white population growth. Government expenditures (except for sanitation) are uncorrelated with urban growth. Government debt is positively correlated with later growth.
\end{abstract}

Edward L. Glaeser

Department of Economics

113 Littauer Center

Harvard University

Cambridge, MA 02138

and NBER

Andrei Shleifer

Department of Economics

Harvard University

Littauer Center 315

Cambridge, MA 02138

and NBER
José A. Scheinkman

Department of Economics

University of Chicago

1126 East 59th Street

Chicago, IL 60637 


\section{Introduction}

Over the last 30 years, growth experiences of the United States cities varied widely. The population of some grew many times while other cities virtually disappeared. Some dispersion of growth experiences can be explained by geographic factors, such as the movement of population west and south. But what are the economic forces that explain city growth over the last 30 years in a cross-section of the United States cities?

In this paper, we empirically investigate these questions. We examine population growth experiences of 203 large US cities between 1960 and 1990 as a function of their location, initial population, initial income, past growth, education of the labor force, output composition, unemployment, inequality, racial composition, segregation, size of government and several other factors. The primary purpose of the analysis is descriptive: to understand which cities grew.

As a description, this analysis continues an extensive regional growth literature, including the studies by Borts (1960), Kain and Neidercorn (1962), Mills (most recently, 1992) and others. Our focus on human capital as a determinant of city growth is particularly closely related to Chinitz (1962), who emphasized the connection between urban success and the transmission of entrepreneurial skills. Similar arguments have been made by Jacobs (1969) and Marshall (1890).

In addition, our analysis aims to contribute to the recent studies of economic growth. Starting with Baumol (1986), Delong (1988) and Barro (1991), economists have compared income growth experiences of different countries as a function of their characteristics. These studies typically find weak evidence of convergence of incomes between countries, and stronger evidence that education, physical investment, political stability, and openness to trade contribute to growth. Other studies, including Barro and Sala i Martin (1991) and Blanchard and Katz (1992), looked at growth experiences of U.S. states. Barro and Sala i Martin find much more income convergence between 
states than between countries. Blanchard and Katz show that employment growth in different states is very persistent, while unemployment is not. ${ }^{1}$

Looking at cities complements looking at countries and states in three ways. First, unlike countries, cities are completely open economies, with tremendous movement of capital, labor, and ideas between them. Cities are more specialized (and less arbitrary) economic units than states, and hence, it may make more sense to study the movement of resources and convergence between cities than between states. National boundaries that bar factor mobility and industrial diversification that eliminate the gains from such mobility add complications to work on cross-national studies. Cities allow us to look at economic growth stripped of these concerns.

Second, many of the cross-sectional studies of growth, particularly across countries, address the ideas that are important for growth. Various versions of this idea include external benefits of physical capital or disembodied knowledge (Romer 1986), human capital (Lucas 1988), particular industries, such as manufacturing or high technology industries (Porter 1991), and various other spillovers. Glaeser, Kallal, Scheinkman and Shleifèr (1992) explored empirically whether technological externalities important to city growth are prevalent within or between industries, and found evidence of the importance of cross-industry externalities. This paper complements the earlier one, in that it focuses on whole cities rather than individual industries and on sources of city-wide externalities, such as those from human capital.

Third, recent studies of economic growth across countries have focused on political and social, as well as economic determinants of growth. For example, several studies starting with Barro (1991) have shown political instability is bad for growth, while Alesina and Rodrick (1991) and others have argued that inequality is bad for growth; Delong and Shleifer (1993) have shown that limited government, as opposed to absolutist government, is good for growth of medieval cities. This paper will use some political and social characteristics of cities to provide further evidence on the importance of social and political factors for growth.

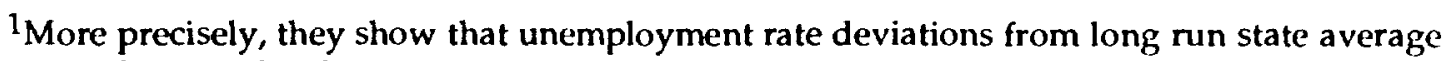
unemployment levels are not persistent.
} 
Section II presents a formal framework for our empirical work. Section III describes our data. Section IV then presents our results on the relationship between economic characteristics of cities and their growth. Section $V$ focuses on social and political characteristics of cities. Section VI concludes.

\section{A Framework}

This section provides a formal setting for our empirical work. ${ }^{2}$ Cities will be treated as separate economies that share common pools of labor and capital. Differences in urban growth experiences cannot then come from savings rates or exogenous labor endowments. Because of our assumption of shared labor and capital, cities differ only in the "level of productivity" and their "quality of life." Total output in a city is given by:

$$
A_{i, t} f\left(L_{i, l}\right)=A_{i, r} L_{i, l}^{\sigma} .
$$

where $A_{i, t}$ represents the level of productivity in city $i$ at time $t . L_{i, t}$ denotes population of city $i$ at time $t, f($.$) is a common (across cities) Cobb-Douglas$ production function with coefficient $\sigma$. are a nationwide production function and production parameter. We interpret $A_{i, t}$ broadly: urban differences in the productivity of labor come from many social, technological, and political sources.

The labor income of a potential migrant will be the marginal product of labor: ${ }^{3}$

$$
W_{i, l}=\sigma A_{i, l} L_{i, l}^{\sigma-1}
$$

Total utility equals wages multiplied by a quality of life index. We assume that this index is declining in the size of the city, or, using a simple functional form:

$$
\text { Quality of Life }=Q_{i, t} L_{i, t}^{\delta},
$$

\footnotetext{
${ }^{2}$ This framework is an extension of the framework used in Glaeser et al. (1992).

${ }^{3}$ Assuming wages are average output makes no qualitative difference to the calculations.
} 
where $\delta>0$. Quality of life is meant to capture a wide range of factors including crime, housing prices, and traffic congestion. Total utility of a potential migrant to city $i$ is:

$$
\text { Utility }=\sigma A_{i, \ell} Q_{i, r} L_{i, t}^{\sigma-\delta-1}
$$

We initially assume free migration across cities. This assumption ensures constant utilities across space at a point in time, so each individual's utility level in each city must equal the reservation utility level at time $t, \underline{U}_{t}$. Thus, for each city:

$$
\log \left(\frac{U_{t+1}}{\underline{U_{1}}}\right)=\log \left(\frac{A_{i, t+1}}{A_{i, t}}\right)+\log \left(\frac{Q_{i, t+1}}{Q_{i, t}}\right)+(\sigma-\delta-1) \log \left(\frac{L_{i, t+1}}{L_{i, t}}\right)
$$

We also assume that:

$$
\begin{aligned}
& \log \left(\frac{A_{i, f+1}}{A_{i, 1}}\right)=X_{i, 1} \beta+\varepsilon_{i, \delta+1} \text {, and } \\
& \log \left(\frac{Q_{i, t+1}}{Q_{i, \ell}}\right)=X_{i, \iota^{\prime}}^{\prime} \theta+\zeta_{i, t+1},
\end{aligned}
$$

where $X_{i t}$ is the vector of city characteristics at time $t$ which determine the growth in both the quality of life in the city and the growth of city level productivity. Combining (2.5), (2.6a) and (2.6b) yields:

$$
\begin{gathered}
\log \left(\frac{L_{i, I+1}}{L_{i, t}}\right)=\frac{1}{1+\delta-\sigma} X_{i, t}^{\prime}(\beta+\theta)+\chi_{i, l+1}, \text { and } \\
\log \left(\frac{W_{i, l+1}}{W_{i, t}}\right)=\frac{1}{1+\delta-\sigma} X_{i, t}^{\prime}(\delta \beta+\sigma \theta-\theta)+\varpi_{i, l+1, l}
\end{gathered}
$$


where $\chi_{i t}$ and $\varpi_{i t}$ are error terms uncorrelated with urban characteristics ${ }^{4}$ The net result of this exercise is that employment growth regressions $a n$ be interpreted as showing how city level variables ( $X$ 's) determine the $\mathrm{m}$ of quality of life and productivity growth). The wage growth regressions can be thought of as showing a weighted average of the productivity growth and $\sigma-1$ times quality of life growth.

One difficulty in interpreting wage growth regressions is that they may be reflecting population composition changes as well as compensation charges. While our model is a model of homogeneous labor (like most growth models), heterogeneity of labor is a principal feature of urban growth. We will handle this problem by (1) discussing how our results might be interpreted in a heterogeneous labor model and (2) examining movements of population subgroups, to allow different urban characteristics to atract different people differently.

\section{Migration vs. Convergence}

A negative correlation between initial wages and wage growth (convergence) might occur because (1) technology improves more slowly in advance sties (real convergence) or (2) because the in-migration of labor to high wage regions caused the wages in those regions to decline. For the rcond explanation to make any sense it must be true that labor responds slowly to shocks in local labor demand. To examine this question, and to create inore generality, this subsection creates a model with migration costs and delityed labor supply responses to local shocks.

We assume that the quality of life to potential migrants declines not only in the level of population but also in the growth rate of population. This decline might occur because the costs of migration are rising in the nurs of in-migrants. A negative connection between quality of life and growth right also occur because it takes time to build certain public goods, or basic infrastructure, or housing, and the residents of quickly growing cities sulier in

\footnotetext{
${ }^{4}$ Formally, $\chi_{i t}=\left(\log \left(\underline{U}_{t+1} / \underline{U}_{t}\right)+\varepsilon_{i t+1}+\zeta_{i t+1}\right) /(1+\delta-\sigma)$, and $\omega_{i t}=\left((\sigma-1) \log \left(\underline{U}_{t+1} / \underline{U}_{t}\right)+\delta \varepsilon_{i t+1}+(\sigma-\right.$ 1) $\left.\zeta_{i t+1}\right) /(1+\delta-\sigma)$.
} 
terms of quality of life until those cities are built up. Quality of life now becomes:

$$
\text { Quality of Life }=Q_{i, t} L_{i, t}^{-\delta_{1}}\left(\frac{L_{i, t}}{L_{i, l-1}}\right)^{-\delta_{2}}
$$

In this case the correctly specified wage growth equation is:

$$
\log \left(\frac{W_{i, t+1}}{W_{i, l}}\right)=\frac{1}{1+\delta_{1}+\delta_{2}-\sigma} X_{i, l}^{\prime}(\delta \beta+\sigma \theta-\theta)-\frac{\delta_{2}}{1+\delta_{1}+\delta_{2}-\sigma} \log \left(\frac{L_{i, t}}{L_{i, t-1}}\right)+\Phi_{i, t+1}
$$

In the case where lagged growth rates of population are omitted from the regressions and $\delta_{2} \neq 0$, then the coefficients on initial characteristics will be biased (and in particular, the coefficient on initial wages should be biased downwards since current wages are positively correlated with lagged growth). Including lagged population growth rates into a wage growth regression is a test of the existence of this bias. As long as the coefficient on the lagged population growth rate is zero, we can accept that $\delta_{2}=0$. If the coefficient is non-zero, then we must concern ourselves with the possibility that convergence comes from in-migration slowly fulfilling labor demand, and wages being driven by in-migration.

Controlling for lagged growth rates does, however, potentially have costs. If the first version of our model is correct, and our measures of the $X$ variables are imperfect, and the true $X$ variables are correlated with lagged growth (perhaps because lagged growth came about because of lagged $X$ variables) then controlling for lagged growth rates will decrease the signal to noise ratio in the $X$ variables and spuriously lower of the coefficients on these variables.

\section{Data Description}

The analysis in this paper is based on a sample of 203 US cities between 1960 and 1990, although we will use some information from 1950. The data were hand-collected from County and City Data Books (1950, 1960, 1970), the 1990 census (earlier censi provided the basis or the Data books --the data are absolutely comparable), and from Taeviser and Taeuber (1965). Sample 
selection is primarily determined by our reliance on Taeuber and Taeuber for racial characteristics of cities: they looked at all United States cities which in 1960 had over 1,000 occupied housing units with a non-white head. the resulting sample of 203 cities includes all but one of the largest 100 cities in the United States, but oversamples Southern cities in the next 100. We have verified that none of the principal results of this paper change if we restrict attention to the largest 100 cities.

Table 1 presents the means and correlations of the variables used in this study (Appendix 1 provides variable definitions). The average city population in our sample of 203 cities is 269,000 in 1960 , growing to an average of 288,000 in 1990, which amounts to only $8.5 \%$ growth over the whole period. East St. Louis shrunk the most in this sample (70 percent over 30 years) whereas Las Vegas grew the most (139 percent over 30 years). In this sample, $40 \%$ of the cities are in the South, $27 \%$ are in the Central Region, $19 \%$ are in the Northeast and the remaining $14 \%$ are in the West. In 1960, these cities have an average of $25.5 \%$ of their activities in manufacturing, an employment rate of $5.4 \%$, black population equal to $18 \%$ of total, and the average median years of schooling of the population above 25 years old of 10.8 years. However, as Table 1 illustrates, there is a great deal of variation in all of these variables.

The correlation matrix points to some obvious, and some less obvious, results. The omitted dummy in this sample is for Western cities. The correlation matrix shows that Southern cities in the sample tend to have relatively smaller populations, somewhat smaller median education levels, dramatically lower per capita incomes, lower unemployment, lower commitment to manufacturing, and much higher segregation than average. Northeastern cities, in contrast, are large, have surprisingly low median levels of education, higher per capita income and unemployment, a much higher fraction of output in manufacturing, and lower segregation. Educated cites tend to have a higher per capita income, lower unemployment and lower share of employment in manufacturing. In general, the correlations are what one might expect.

A more casual look at the data is provided in Appendix II which describes the data in more detail for four cities: Phoenix, Arizona, Greensboro, North 
Carolina, Yonkers, New York, and East Chicago, Indiana. Phoenix's population has almost doubled in the past 30 years and it is now one of the ten largest cities in America. Phoenix is now, and was in 1960, a well educated city, ${ }^{5}$ whose success has not come in traditional manufacturing (which was always a small part of the economy) but rather in services and high tech areas (electronic machinery is its largest industry). Government seems to have performed two services in increasing Phoenix's population: (1) a growing state government provided more employment for workers in Phoenix ${ }^{6}$ and (2) municipal (and state) authorities seem to have kept a strong commitment to laissez-faire. ${ }^{7}$ Durham is also an urban success (albeit on a smaller scale), growing $55.7 \%$ over the sample period. Durham benefited from its access to a center of human capital (Duke University), ${ }^{8}$ low wages and the usual regional advantages that made southern cities successful in this period.

If Yonkers, NY, existed on a featureless plain, it would have contained in 1960 three of the ingredients for disaster among post-war American cities: an orientation towards manufacturing, a high unemployment rate, and a low level of education. However, Yonkers held its ground, losing only $.3 \%$ of its population since 1960. The explanation is simple-- the flight to the suburbs from New York saved Yonkers from precipitous decline. 9 Suburbanization could not save East Chicago. Despite its proximity to a major city, which has been rapidly suburbanizing (both North and West), East Chicago's population fell $60 \%$ since 1960 , because (1) the extraordinarily high share of it: labor force in manufacturing $(58.9 \%$, more than double Yonkers), and (2) it's low levels of high school graduates (27.3\% or about one-half of Yonkers).

\footnotetext{
${ }^{5}$ The median years of education were 11.8 .

${ }^{6}$ Ades and Glaeser (1995) argue that capitals grow because of resources of the hinterland that are spent in the capital.

${ }^{7}$ Local government expenditures per capita are only $60 \%$ of the average per capita expenditures.

${ }^{8}$ While Durham's median years of schooling were low (9.9 years), it had a high (12.3\%) percent of college graduates.

${ }^{9}$ This example suggests that cities' outcomes are often a function of neighboring areas attributes. We have dealt with this problem by running regressions both for cities and for SMSAs.
} 


\section{Economic determinants of city growth}

In this paper, our primary measure of city growth is the growth of its population. ${ }^{10}$ Population growth might not be appropriate for a country, for example, because population is relatively immobile and differences in population growth mainly reflect differences in fertility. Income growth, however, is a natural measure of productivity growth across countries precisely because of this immobility of labor. With US cities, as with US states, however, the situation is radically different, and the response to growth opportunities takes place through migration (Blanchard and Katz 1992). As we saw in the model, income growth captures some portion of productivity growth as long as there is congestion in the leisure sector, but income growth also captures declines in quality of life and is a less perfect measure of general urban success.

One concern about our population measure is the movement of population to city suburbs, even when people continue to work in the city. For example, when people avoid pollution, bad schools, or racial tension in a city, they move to the suburbs, and the city population falls even if its employment doesn't solely because of suburbanization. To address this concern, we examine not only the growth of city populations, but also the growth of the populations of standard metropolitan statistical areas (SMSAs) as a function of city characteristics.

Table III presents the basic results on city and SMSA population growth as a function of initial conditions. The first column presents the regression of city population growth on only the initial population, initial income per capita, and geographical dummies. The regression confirms the well-known fact that (the omitted) Western cities grew the fastest, Southern cities grew the second fastest, Central cities third fastest, and Northeastern cities, the slowest during this sample. These regional dummies cannot be easily rendered insignificant with economic variables on which we have observations, suggesting that weather and other regional characteristics have played an important role in migration and hence the growth of cities.

10 Using employment growth provides qualitatively equivalent results in almost all cases. 
This regression also shows that population of larger cities grew slower; a finding which is not robust. More interestingly, there is no evidence that the population of richer cities grew slower, which is not consistent with the basic convergence idea that capital (and with it, labor) should move to regions where wages are lower. In later regressions, we will use region dummies, initial population, and initial income per capita as permanent controls.

The middle two regressions in Table III begin to address the issue of persistence of growth rates. They show that cities that attract migration 11 and cities which grew faster between 1950 and 1960, also continued to grow faster after 1960. These results are highly statistically significant, and consistent with similar finding by Blanchard and Katz (1992) for states. We return to persistence of growth rates later, when we split the sample period. The fourth regression in Table I repeats the basic specification for SMSAs. Again, there is no evidence of convergence. One interesting finding is that the movement of population to the suburbs seems to be more important in the Northeast than in other regions, which makes Northeastern SMSAs look not as bad, in terms of population growth as Northeastern cities proper. SMSAs also show less population convergence than cities. Indeed, limits on available land should make congestion more important in the densely populated inner city than in the much more open SMSA.

Regression (5) in Table III presents the results for per capita income growth. The only significant coefficient is the South dummy, which confirms the well-known result that Southern incomes grew faster. In the West, population grew the fastest; in the South, income did. As before, there is no significant evidence of convergence.

Regression (6) repeats (5) controlling for past population growth. This procedure follows Equation $\left(2.8^{\prime}\right)$ and is meant to estimate $\delta_{2}$. The insignificant correlation between lagged population growth and future income growth fails to reject the hypothesis that $\delta_{2}=0$, or that the second effect is statistically insignificant. These results (and unreported results that show

${ }^{11}$ By definition these cities have had high levels of gross population growth. 
that none of our subsequent income change results change if we control for lagged employment growth) allow us to feel somewhat more confident that our income change results are actually reflecting productivity movements, not a gradual return to nationwide average wages from slow migration.

Table IV examines the relationship between city population growth and the initial manufacturing share of output. The first column demonstrates that the population of cities significantly involved in manufacturing grew much less than that of cities less involved in manufacturing. This result holds true even controlling for regions and other initial conditions examined in Table III. The next two columns show that a high initial exposure to manufacturing had an adverse effect on the growth of more manufacturing and non -manufacturing employment in a city, and not just its population. Moreover, manufacturing cities' populations relatively declined not just because people escaped to the suburbs; the population of whole SMSAs grew slower as well. Finally, manufacturing cities relatively declined not only in terms of population, but also in terms of per capita income. A one standard deviation in manufacturing's share of employment creates a 3.4\% decline in income between 1960 and 1990.

These results suggest that cities followed the fortunes of the industries that they were exposed to initially. Non-manufacturing activities did not move into cities where manufacturing declined; rather, the population of these cities itself (relatively) declined through emigration, and incomes fell. These results seem particularly supportive of a vintage capital model, where cities that invested in older types of capital do not replace that capital as it becomes obsolete because (1) existing capital represents a sunk investment and (2) the pre-existing capital "crowds out" newer capital.12 As the capital becomes more out-of-date the marginal product of labor, the wage rate and eventually population falls.

Table $\mathrm{V}$, which focuses on initial unemployment and subsequent population growth, presents a similar picture. Initial unemployment rate reduces subsequent population growth of both the city and its SMSA. The middle

${ }^{12}$ This crowding out may occur because scarce resources (such as land) are usced with the older capital. 
columns show that a high initial unemployment rate adversely affects the growth rate of both employed and unemployed populations, and not just the whole city population. There are two natural interpretations of this effect: (1) cities with high unemployment rates declined as workers responded to business cycle shocks through emigration and (2) unemployment is proxying for omitted human capital variables and cities with high unemployment lacked the skilled labor forces necessary for success in our period. ${ }^{13}$ The last regression in Table $\mathrm{V}$ also shows that initial unemployment reduces subsequent income growth; a one standard deviation drop in the unemployment rate creates a $3.75 \%$ fall in income.

Table VI presents results on the initial education levels and subsequent population growth. The first column of Table VI shows that initial median years of schooling exert a positive and significant influence on the subsequent population growth, using our standard controls as well as the initial unemployment rate and manufacturing share.14 Once we control for education, we also get the income convergence result, namely that cities with higher initial per capita income grow less. This result is similar to Barro's (1991). ${ }^{15}$ A closer inspection of what it is about schooling that matters shows that the percent of the population with 12 to 15 years (high school graduates or some college) is more important than the percent of the population with over 16 years(college graduates). This result suggests the importance of a welleducated labor force, not just of the top of the education distribution. Interestingly, median years of schooling are not significant if we look at the SMSA population, suggesting that schooling may have contributed to suburbanization and not just city growth.

One interesting question in the theory of economic growth is whether the average or the total quantity of human capital speeds up economic growth. One can build human capital spillover models in the spirit of Lucas (1988) in which growth is proportional to either total or average education. As a rough test of these theories, Table VI present a regression in which both the average

${ }^{13}$ High levels of unemployment may also generate negative externalities.

${ }_{14}$ Miracky (1994) also finds a correlation between schooling levels and urban growth between 1977 and 1990.

${ }^{15}$ This resulted is not changed when we control for past population growth rates, so we do not believe that it is simply the outcome of wages falling as migrants catch up with demand. 
education, and a proxy for the total stock of education, are included. The results suggest that average education matters and total education does not. ${ }^{16}$

Finally, the last regression in Table VI examines the effect of education on subsequent per capita income growth. The basic result, similar to that for countries, is that cities with a higher median years of schooling show faster subsequent per capita income growth. Here a one standard deviation rise in median years of schooling raises income $2.78 \%$ over the period.

Overall the results on income growth closely resemble the results on population growth. Unemployment lowers growth. Manufacturing lowers growth. Initial education raises growth. The fact that income and population results are in similar direction suggests that either (1) movements in wages and population are generally determined by productivity changes not quality of life changes (i.e. in equations (2.7) and (2.8), the $\beta$ terms are much larger than the $\theta$ terms in absolute value), or (2) the same factors that cause increases in productivity cause decreases in quality of life (i.e. the $\boldsymbol{\beta}$ terms have the reverse sign as the $\theta$ terms). We find the second explanation less plausible. ${ }^{17}$ An additional possibility is that perhaps the income results are reflecting changes in labor force composition and it is true that cities with growing populations have also had increases in the percent college educated. 18

Tables III through VI have presented some results on the growth of cities over 1960-1990. Since we have some data for 1950, we can actually look at two twenty year periods, 1950-1970 and 1970-1990, as is done in Table VII. Initial unemployment and manufacturing share negatively affect employment

\footnotetext{
${ }^{16} \mathrm{An}$ interesting sidenote is that population growth and income growth are both correlated with growth in percent college educated. Cities become more appealing in this way as they grow. However, we did not find the growth in percent college educated (or any other meaningful measure of human capital stocks) to be significantly related (in either direction) to our initial variables.

${ }^{17}$ The second explanation requires one to believe that unemployment has made cities a more pleasant place to live.

${ }^{8}$ We cannot with our data look at income within subgroups of the population, so it is difficult for us to distinguish whether rises in income represent higher income for all the residents of the city or whether they represent a shift in the human capital composition of the labor force. A preliminary examination of the data has suggested that compositional shifts explain a significant, but not overwhelming, portion of income changes.
} 
growth in both subperiods, although the effect of the initial manufacturing share is insignificant in the second subperiod, and high unemployment appears to be worse for growth after 1970. The more interesting result in this table is that the effect of median years of schooling on subsequent growth has increased after 1970 (although this result is not statistically significant). This result is consistent with studies that show the increased importance of education after 1970 in other contexts (for example, Murphy and Welch 1991).

In summary, the results for cities are surprisingly similar to the results for countries in that cities with "good" characteristics, such as low manufacturing exposure, high education, and low unemployment, grow faster. There is little evidence of that bigger cities have a lower population growth, or that richer cities have a lower income growth (although income convergence is stronger once we control for city characteristics).

\section{Population growth and social characteristics of cities.}

In this section, we examine the effect of several social and political characteristics on the growth of US cities, 1960-1990. The social meàsure we use to proxy for social tension in a city are income (and education) inequality, racial composition, and segregation of the population. We also look, at the effect of composition of government spending on subsequent growth.

Table VIII presents the results on city population growth and inequality, controlling for the initial conditions that have been shown to matter so far. Controlling for mean income, the percent of the population that is rich (has income above 10,000 in 1960) raises city growth although this result disappears if we look at the SMSA. In addition, the percent of the population that is poor (has income below $\$ 3,000$ in 1960) has no effect on city growth, but substantially raises SMSA growth. This result suggests that, in this period, social tensions resulting from substantial poverty in a city manifested themselves through suburbanization. At the same time, the second column presents the surprising result that a high percentage of uneducated people is associated with higher city growth, which suggests that an abundance of inexpensive, low human capital labor attracted capital, or, alternatively, that we are not fully accounting for regional variation. 
Regression (5) shows the connection between schooling inequality and income growth. Urban income growth is positively related to the share of college educated workers. Median years of schooling becomes insignificant when college educated workers share is controlled for.

Table IX presents the results on city growth and racial composition. Without any but our standard Table III controls, percent non-white seems to weakly slow down city growth, although this result is not particularly robust, and disappears when more controls, such as initial unemployment, manufacturing share, and median years of schooling are added. Obviously, race in this sample is correlated with the initial economic characteristics of a city.

We also use the segregation index from Taeuber and Taeuber (1965), defined as the percent of non-whites who would have to move so that the white/non-white distribution is uniform over blocks of a city. ${ }^{19}$ A value of 0 would correspond to a perfectly integrated city, a value of 100 would correspond to a city where no whites live on blocks with any non-whites. The segregation index has no effect on subsequent growth. However, weighted segregation, defined as the segregation index times the percentage of the population that is black (to differentiate between segregated cities with a lot of blacks and those with a few) has a positive influence on future growth. Another way of seeing this result is by looking only at cities with over $10 \%$ non-whites. For these cities, segregation positively affects growth, perhaps because segregation lessened racial discord or because whites demanded segregation. This result is inconsistent with Benabou (1993), who argues that under certain conditions segregation is costly to growth because of diminished knowledge spillovers. ${ }^{20}$

Table $X$ examines the relationship between city growth and the levels and composition of government receipts and expenditures in 1960. It does not appear that either 1960 per capita revenue or 1960 per capita expenditure

\footnotetext{
${ }^{19}$ The index assumes only non-whites moving.

${ }^{20}$ Benabou's results would not hold if the spillovers between whites were stronger than the spillovers between whites and non-whites.
} 
significantly influence subsequent population growth. Expenditure levels in 1960 are positively related to later income growth, but this result is not robust. However, 1960 debt levels (holding revenue constant) are positively associated with subsequent growth. ${ }^{21}$ In addition, a higher fraction of expenditures that goes to sanitation (perhaps a useful type of government spending) is associated with faster subsequent growth. Interestingly, a higher fraction of expenditures that goes to highway construction-- a plausible measure of infrastructure spending-- is not associated with higher subsequent growth. In sum, there are no striking results on the effect of government revenue or spending on growth, in line with much of the evidence on growth of countries.

\section{Conclusion}

This paper has presented a variety of partial correlations between growth of city populations and these cities' initial characteristics. A key variable for cities, as for countries, is initial education level of the population. Several other economic variables, such as initial-unemployment and exposure to manufacturing, proved important as well. We were relatively less sùccessful in identifying important social and political variables. Although we did find that our weighted segregation measure was not negatively correlated with income and population growth. In many respects, however, the story of growth of cities is similar to that of the growth of countries. Since cities' differences are not created by different savings rates, or different labor force endowments, our results suggest that higher education levels influence later growth not through savings but through influencing the growth of technology.

Many of the most interesting explanations for the connection between growth and initial human capital levels across countries have focused on productive externalities generated by schooling. Since these externalities should be particularly prevalent in cities, finding a connection between growth and initial schooling across urban centers supports the view of schooling as a

\footnotetext{
${ }^{21}$ This correlation between debt levels and later growth may be because higher, expected growth levels made it cheaper to borrow or because cities anticipating high levels of population growth invested heavily in infrastructure to serve that growth.
} 
generator (through spillovers) of growth. The robust relationship between schooling and growth for SMSAs, city employment, and city income growth provide more evidence supporting the positive role of education in economic expansion. 


\section{References}

Ades, A. and E. Glaeser (1995) "Trade and Circuses: Explaining Urban Giants," Quarterly Journal of Economics, forthcoming.

Alesina, A. and D. Rodrik (1991) "Distributive Politics and Economic Growth," mimeographed.

Barro, R. (1991) "Economic Growth in a Cross Section of Countries," Quarterly Journal of Economics CVI: 407-444.

Barro, R. and X. Sala i Martin (1992) "Convergence" Journal of Political Economy 100: 223-251.

Baumol, W.J. (1986) "Productivity Growth, Convergence, and Welfare: What Does the Long Run Data Show," American Economic Review 76: 10721085.

Benabou, R. (1993) "Working of a City: Location, Education and Production," mimeographed.

Blanchard, O. and L. Katz (1992) "Regional Evolutions," Brookings Papers on Economic Activity.

Borts, G. (1960) "The Equalization of Returns and Regional Economic Growth," American Economic Review 50: 319-347.

Chinitz, B. (1962) American Economic Review, Papers and Proceeding 52: 279-289.

DeLong, J.B. (1988) "Productivity Growth, Convergence and Welfare: Comment," American Economic Review 78: 1138-1154.

DeLong, J.B. and A. Shleifer (1993) "Princes and Merchants: European City Growth before the Industrial Revolution," Journal of Law and Economics (forthcoming).

Glaeser, E., Kallal, H., Scheinkman, J., and A. Shleifer (1992) "Growth in Cities," Journal of Political Economy 100: 1126-1152.

Jacobs, J. (1969) The Economy of Cities. New York: Vintage.

Kain, J. and D. Neidercorn (1963) "An Econometric Model of Metropolitan Development" in Regional Science Association Papers, 11.

Lucas, R.E. (1988) "On the Mechanics Economic Development," Journal of Monetary Economics 12: 3-42.

Marshall, A. (1890) Principles of Economics London: Macmillan.

Mills, E.S. (1992) "Forecasting the Growth of Metropolitan Areas, "mimeographed.

Miracky, W. (1994) "Cities and the Product Cycle," mimeographed.

Murphy, K. and F. Welch (1992) "The Structure of Wages," Quarterly Journal of Economics $107: 285-326$.

Porter, M. (1990) The Comparative Advantage of Nations. New York: Free Press.

Romer, P. (1986) "Increasing Returns and Long-Run Growth," Journal of Political Economy 94: 1002-1037.

Taeuber, A. and Taeuber, K. (1965) Negroes in Cities. McGraw Hill. 


\section{Appendix 1: Description of Variables}

Population(City): This variable comes from the 1950-1970 county and city data books and is the number of persons living with the political unit of the city. It does not count commuters. This variable is ultimately derived from the census.

Population (SMSA): This variable again comes from the 1950-1070 county and city data books and the 1990 census. Since SMSA definitions have changed over the relevant sample period, we have used the country definitions from 1990 and reconstructed SMSAs in 1960 using these 1990 definitions. The population counts themselves come from the census.

Regions: The four regional classification are standard. We used the regional definitions given by Taeuber and Taeuber (1965).

Per Capita Income: This variable was created from two variables included in the city and county data books. Aggregate income is described as the amount received by all income recipients 14 years and older. This variable was then divided by the population measure.

Manufacturing's Share: This (again from the data books, which will be our sources for all the remaining variables unless noted) variable represents the share of workers who are employed who worked in manufacturing industries, which means specifically industries with SIC codes 20-39.

Unemployment Rate: This variable refers to the share of labor force that is currently unemployed. The usual problems about workers who have dropped out of the labor force applies.

Median Years of Schooling: This variable gives the median years of schooling for all persons 25 years and older.

$16+, 12-16,12$ - Years of Schooling Share of Population: These variables again refer to the schooling of persons 25 years and over. 
Percentage Non-White: This refers to the share of the population not classified as whites and includes Hispanics.

Segregation Index: This index comes from Taeuber and Taeuber (1965) and is described in the text of our paper and their book.

3000-10,000+ Share of Population: These variables refer to the shares of the population that earn less than 3000 or more than 10,000 dollars per year among the working population.

Government Expenditures, Revenues, and Debt: These variables are from the County adn City Data books and are formed by dividing total government expenditures, revenues, and debt by population figures described above.

Change as a Proportion of Population (Tables 7 and 11): In these tables changes of subgroups were found by dividing the absolute population changed in the subgroup by the city's initial total population. 


\section{Appendix II: Description of Four Cities}

Durham, North Carolina

Population

\%High School

Graduates

Per capita Income

$\%$ Manufacturing

\%Unemployment

$\%$ Non-White

Per Capita Government

Expenditures
1960

1990

78,302

$38.2 \%$

$78.5 \%$

$\$ 1,1647$

$\$ 10,257$

$25.4 \%$

$N / A$

$4.9 \%$

$4.5 \%$

$36.3 \%$

$48.3 \%$

$\$ 101.2$

$\$ 468.0$

1960

1990

57,669

33,892

\%High School

$27.3 \%$

$57.7 \%$

Graduates

Per capita Income

$\$ 1,821$

$\$ 7,905$

$\%$ Manufacturing

$58.9 \%$

$31.5 \%$

$\%$ Unemployment

$4.5 \%$

$14.3 \%$

$\%$ Non-White

$24.0 \%$

$62.0 \%$

Per Capita Government

$\$ 143.9$
$\$ 1135.0$

Expenditures 
Phoenix, Arizona

Population

\%High School

Graduates

Per capita Income

\%Manufacturing

\%Unemployment

$\%$ Non-White

Per Capita Government

Expenditures

Yonkers, New York

Population

\%High School

Graduates

Per capita Income

\%Manufacturing

\%Unemployment

$\%$ Non-White

Per Capita Government

Expenditures 
TABLE I: MEANS AND STANDARD DEVIATIONS

CITY VARIABLES

\begin{tabular}{|c|c|c|c|c|}
\hline CHANGES & Mean & Std Dev & Minimum & Maximum \\
\hline Log Growth of Population 1960-1990 & 0.085 & 0.396 & -0.691 & 1.389 \\
\hline Log Growth of Population 1950-1960 & 0.037 & 0.054 & -0.065 & 0.309 \\
\hline \multicolumn{5}{|l|}{1960 STARTING VARIABLES } \\
\hline Log of Population & 11.864 & 0.931 & 10.168 & 15.867 \\
\hline Per Capita Income $(\$ 1000)$ & 1.993 & 0.4088 & 1.150 & 3.872 \\
\hline Migrants Per Capita & 17.154 & 8.588 & 4.2 & 42.6 \\
\hline \multicolumn{5}{|l|}{ GEOGRAPHICAL } \\
\hline South & 0.397 & 0.490 & 0 & 1 \\
\hline Central & 0.270 & 0.445 & 0 & 1 \\
\hline Northeast & 0.191 & 0.394 & 0 & 1 \\
\hline \multicolumn{5}{|l|}{ RACE } \\
\hline Segregation Index & 86.19 & 7.46 & 60.4 & 98.1 \\
\hline Weighted Segregation Index & 1.589 & 1.090 & 0.145 & 5.054 \\
\hline Percent Non-White & 18.09 & 11.91 & 2.1 & 57.5 \\
\hline \multicolumn{5}{|l|}{ LABOR FORCE } \\
\hline Unemployment Rate & 5.4 & 1.7 & 1.9 & 10.5 \\
\hline Manufacturing Share of Employment & 0.255 & 0.118 & 0.043 & 0.589 \\
\hline \multicolumn{5}{|l|}{ EDUCATION } \\
\hline Median Years of schooling & 10.833 & 1.116 & 8.4 & 13.7 \\
\hline$\%$ of pop with $16+$ yrs of school & 8.9 & 4.533 & 2.5 & 38.7 \\
\hline$\%$ of op with $12-15$ yrs of school & 33.781 & 6.463 & 17.4 & 49.5 \\
\hline$\%$ of op with less than 5 yrs of school & 8.333 & 3.948 & 1.9 & 21.4 \\
\hline \multicolumn{5}{|l|}{ INCOME INEQUALITY } \\
\hline$\%$ if pop earning under $\$ 3000$ & 19.437 & 7.411 & 5.0 & 41.6 \\
\hline$\%$ of op earning over $\$ 10,000$ & 15.98 & 6.383 & 5.7 & 43.8 \\
\hline \multicolumn{5}{|l|}{ GOVERNMENT } \\
\hline Per capita Revenue & 103.639 & 64.423 & 11.775 & 581.353 \\
\hline Property tax share of revenue & 0.445 & 0.175 & 0.082 & 0.876 \\
\hline Intergov funds share of revenue & 0.161 & 0.109 & 0.0002 & 0.516 \\
\hline Per capita Expenditure & 110.002 & 66.107 & 13.931 & 634.169 \\
\hline Police share of expenditure & 0.121 & 0.043 & 0.039 & 0.240 \\
\hline Highway share of expenditure & 0.133 & 0.070 & 0.014 & 0.428 \\
\hline Sanitation share of expenditure & 0.143 & 0.083 & 0.026 & 0.534 \\
\hline Per Capita Debt & 205.326 & 164.684 & 8.146 & 1679.698 \\
\hline
\end{tabular}


TABLE II:

RAW CORRELATIONS, CITY VARIABLES

\begin{tabular}{|c|c|c|c|c|c|c|c|c|}
\hline CHANGES & GR6090 & GR5060 & LNPOP & PCINC & STH & CENT & $\mathrm{NE}$ & SEG \\
\hline Log Growth of Population $1960-1990$ & 1 & 0.52 & -0.08 & --0.02 & 0.26 & -0.28 & .0 .32 & 0.08 \\
\hline $\begin{array}{l}\text { Log Growth of Population 1950-1960 } \\
1960 \text { STARTING VARIABLES }\end{array}$ & 0.52 & 1 & -0.02 & 0.00 & 0.23 & -0.15 & .0 .35 & 0.23 \\
\hline Log of Population & -0.08 & -0.02 & 1 & 0.11 & -0.13 & 0.04 & 0.01 & -0.02 \\
\hline $\begin{array}{l}\text { Per Capita Income }(000) \\
\text { GEOGRAPHICAL }\end{array}$ & -0.02 & 0.00 & 0.11 & 1 & -0.47 & 0.07 & 0.22 & -0.40 \\
\hline South & 0.26 & 0.23 & -0.13 & -0.47 & 1 & -0.49 & -0.39 & 0.54 \\
\hline Central & -0.28 & -0.15 & 0.04 & 0.07 & -0.49 & 1 & -0.30 & 0.12 \\
\hline $\begin{array}{l}\text { Northeast } \\
\text { RACE }\end{array}$ & -0.32 & -0.35 & 0.01 & 0.22 & -0.39 & -0.30 & 1 & -0.42 \\
\hline Segregation Index & 0.08 & 0.23 & -0.02 & -0.40 & 0.54 & 0.12 & -0.42 & 1 \\
\hline $\begin{array}{l}\text { Percent Non-White } \\
\text { LABOR FORCE }\end{array}$ & -0.04 & -0.17 & -0.02 & -0.38 & 0.51 & -0.21 & -0.16 & 0.34 \\
\hline $\begin{array}{l}\text { Unemployment Rate } \\
\text { Manufacturing Share of Employment } \\
\text { EDUCATION }\end{array}$ & $\begin{array}{l}-0.25 \\
-0.45\end{array}$ & $\begin{array}{l}-0.28 \\
-0.35\end{array}$ & $\begin{array}{l}0.01 \\
-0.02\end{array}$ & $\begin{array}{l}-0.33 \\
-0.01\end{array}$ & $\begin{array}{l}-0.19 \\
-0.48\end{array}$ & $\begin{array}{l}0.01 \\
0.40\end{array}$ & $\begin{array}{l}0.11 \\
0,32\end{array}$ & $\begin{array}{l}-0.13 \\
-0.19\end{array}$ \\
\hline $\begin{array}{l}\text { Median Years of schooling } \\
\text { GOVERNMENT }\end{array}$ & 0.39 & 0.45 & 0.01 & 0.58 & -0.08 & -0.00 & -0.27 & -0.07 \\
\hline $\begin{array}{l}\text { Per capita Revenue } \\
\text { Per capita Expenditure } \\
\text { Per Capita Debt }\end{array}$ & $\begin{array}{l}-0.07 \\
-0.02 \\
0.22\end{array}$ & $\begin{array}{l}-0.09 \\
-0.05 \\
0.23\end{array}$ & $\begin{array}{l}0.26 \\
0.22 \\
0.23\end{array}$ & $\begin{array}{c}0.20 \\
0.14 \\
-0.08\end{array}$ & $\begin{array}{l}-0.14 \\
-0.08 \\
0.21\end{array}$ & $\begin{array}{l}-0.17 \\
-0.20 \\
-0.19\end{array}$ & $\begin{array}{r}0.34 \\
0.28 \\
-0.05\end{array}$ & $\begin{array}{l}-0.26 \\
-0.21 \\
0.17\end{array}$ \\
\hline
\end{tabular}


TABLE II, CONTINUED:

RAW CORRELATIONS, CITY VARIABLES

\section{CHANGES}

\%NONW UNEM MFRG MEDYRS REV EXP DEBT

Log Growth of Population 1960-1990

$-0.04$

Log Growth of Population 1950-1960

$-0.04-0.25$

$-0.45$

0.39

$-0.07$

0.22

$-0.02$

1960 STARTING VARIABLES

Log of Population

Per Capita Income (000)

GEOGRAPHICAI

South

Central

$-0.17-0.28$

$-0.35$

0.45

$-0.09$

$-0.05$

$\begin{array}{rr}-0.02 & 0.01 \\ -0.38 & -0.33\end{array}$

$-0.02$

0.01

0.26

0.23

0.22

$\begin{array}{ll}-0.38 & -0.33\end{array}$

$-0.01$

0.20

$-0.08$

0.14

$\begin{array}{rr}0.51 & -0.19 \\ -0.21 & 0.01 \\ -0.16 & 0.11\end{array}$

$-0.48$

$-0.08$

$\begin{array}{ll}0.40 & -0.00\end{array}$

$\begin{array}{lll}-0.14 & 0.21 & -0.08\end{array}$

$\begin{array}{ll}-0.21 & 0.01 \\ -0.16 & 0.1\end{array}$

0.33

$-0.27$

$-0.17$

$-0.18$

$-0.20$

RACE

Segregation Index

Percent Non-White

LABOR FORCE

Unemployment Rate

$\begin{array}{cc}0.34 & -0.13 \\ 1 & 0.13\end{array}$

$-0.19$

$-0.07$

0.34

$-0.05$

0.28

Manuf. share of Employment

$-0.19$

$-0.26$

$\begin{array}{ll}0.17 & -0.21\end{array}$

0.13

EDUCATION

Median Years of schooling

GOVERNMENT

Per capita Revenue

Per capita Expenditure

Per Capita Debt

$-0.19$

0.29

$-0.38$

0.12

0.10

0.29

$-0.48$

$-0.02$

$-0.11$

0.01

$-0.38$

$-0.50$

0.06

$-0.20$

0.03

$-0.50$

$-0.11$

$-0.02$

$-0.14$

0.05

0.12

0.02

0.06

$-0.20$

$-0.11$

$-0.02$

1

0.51

0.97

0.10

0.01

0.03

$-0.14$

0.51
0.97

1
0.58

0.58
1 
TABLE III: CITY GROWTH AND INITIAL GROWTH CONDITIONS Dependent Variable: Log of Population Growth rate (1960-1990)

\begin{tabular}{|c|c|c|c|c|c|}
\hline Variable & $\begin{array}{c}1 \\
\text { City }\end{array}$ & city & City & $\stackrel{4}{\operatorname{SMSA}^{*}}$ & $\begin{array}{c}5 \\
\text { City } \\
\text { Income }\end{array}$ \\
\hline Intercept & 0.831 & 0.295 & 0.620 & 0.361 & 15.578 \\
\hline Log (Population 1960) & $\begin{array}{l}-0.045 \\
(0.025)\end{array}$ & $\begin{array}{r}-0.016 \\
(0.024)\end{array}$ & $\begin{array}{l}-0.034 \\
(0.024)\end{array}$ & $\begin{array}{c}0.007 \\
(0.026)\end{array}$ & $\begin{array}{l}-0.013 \\
(0.01)\end{array}$ \\
\hline Per Capita Income ( $\$ 1000)$ & $\begin{array}{c}0.068 \\
(0.066)\end{array}$ & $\begin{array}{r}-0.052 \\
(0.063)\end{array}$ & $\begin{array}{c}0.010 \\
(0.064)\end{array}$ & $\begin{array}{c}0.102 \\
(0.116)\end{array}$ & $\begin{array}{r}-0.012 \\
(0.026)\end{array}$ \\
\hline Migrants Per Capita: 1960 & & $\begin{array}{c}0.020 \\
(0.003)\end{array}$ & & & \\
\hline $\begin{array}{l}\text { Log (Population Growth } \\
1950 \text { to } 1960 \text { ) }\end{array}$ & & & $\begin{array}{c}0.251 \\
(0.045)\end{array}$ & & \\
\hline \multicolumn{6}{|c|}{ GEOGRAPHICAL DUMMIES } \\
\hline South & $\begin{array}{l}-0.209 \\
(0.081)\end{array}$ & $\begin{array}{l}-0.214 \\
(0.074)\end{array}$ & $\begin{array}{l}-0.166 \\
(0.076)\end{array}$ & $\begin{array}{c}-0.107 \\
(0.082)\end{array}$ & $\begin{array}{c}0.18 \\
(0.031)\end{array}$ \\
\hline Central & $\begin{array}{l}-0.529 \\
(0.079)\end{array}$ & $\begin{array}{r}-0.374 \\
(0.076)\end{array}$ & $\begin{array}{l}-0.387 \\
(0.076)\end{array}$ & $\begin{array}{r}-0.430 \\
(0.076)\end{array}$ & $\begin{array}{l}0.004 \\
(0.03)\end{array}$ \\
\hline Northeast & $\begin{array}{l}-0.619 \\
(0.082)\end{array}$ & $\begin{array}{r}-0.364 \\
(0.085)\end{array}$ & $\begin{array}{l}-0.405 \\
(0.083)\end{array}$ & $\begin{array}{r}-0.374 \\
(0.088)\end{array}$ & $\begin{array}{l}-0.031 \\
(0.031)\end{array}$ \\
\hline $\begin{array}{l}\mathbf{N} \\
\text { Adi } R^{2}\end{array}$ & $\begin{array}{c}203 \\
0296\end{array}$ & $\begin{array}{c}203 \\
0411\end{array}$ & $\begin{array}{c}197 \\
0373\end{array}$ & $\begin{array}{c}133 \\
0768\end{array}$ & 201 \\
\hline Adj. $R^{2}$ & 0.296 & 0.411 & 0.373 & 0.268 & 0.368 \\
\hline
\end{tabular}

Note: Numbers in Parentheses are standard errors.

*: SMSA regression exludes Las Vegas SMSA. 
TABLE IV: CITY GROWTH AND MANUFACTURING

Dependent Variable: Log of Growth Rate (1960-1990)

\begin{tabular}{|c|c|c|c|c|c|}
\hline Dependent Variable: & $\begin{array}{c}1 \\
\text { City } \\
\text { Total } \\
\text { Popula- } \\
\text { tion }\end{array}$ & $\begin{array}{c}2 \\
\text { City } \\
\text { Manufac- } \\
\text { turing } \\
\text { Employ- } \\
\text { ment }\end{array}$ & $\begin{array}{c}3 \\
\text { City } \\
\text { Non } \\
\text { Manufac- } \\
\text { turing } \\
\text { Employ- } \\
\text { ment } \\
\end{array}$ & $\begin{array}{c}4 \\
\text { SMSA* } \\
\text { Total } \\
\text { Popula- } \\
\text { tion }\end{array}$ & $\begin{array}{c}5 \\
\text { City } \\
\text { Income }\end{array}$ \\
\hline Intercept & 1.167 & -8.398 & 5.622 & 0.560 & 15.703 \\
\hline Log (Population 1960) & $\begin{array}{c}-0.050 \\
(0.025)\end{array}$ & $\begin{array}{c}0.776 \\
(0.076)\end{array}$ & $\begin{array}{c}-0.417 \\
(0.041)\end{array}$ & $\begin{array}{c}0.035 \\
(0.025)\end{array}$ & $\begin{array}{r}-0.015 \\
(0.01)\end{array}$ \\
\hline Per Capita Income $1960(\$ 1000)$ & $\begin{array}{c}0.012 \\
(0.067)\end{array}$ & $\begin{array}{r}-0.062 \\
(0.208)\end{array}$ & $\begin{array}{c}-0.019 \\
(0.095)\end{array}$ & $\begin{array}{c}0.007 \\
(0.112)\end{array}$ & $\begin{array}{l}-0.033 \\
(0.027\end{array}$ \\
\hline Manufacturing Share 1960 & $\begin{array}{c}-0.799 \\
(0.253)\end{array}$ & $\begin{array}{r}-2.482 \\
(0.783)\end{array}$ & $\begin{array}{c}-0.670 \\
(0.355)\end{array}$ & $\begin{array}{c}-0.977 \\
(0.230)\end{array}$ & $\begin{array}{r}-0.283 \\
(0.096)\end{array}$ \\
\hline \multicolumn{6}{|l|}{ GEOGRAPHICAL DUMMIES } \\
\hline South & $\begin{array}{c}-0.244 \\
(0.080)\end{array}$ & $\begin{array}{c}0.144 \\
(0.246)\end{array}$ & $\begin{array}{c}-0.233 \\
(0.114)\end{array}$ & $\begin{array}{c}-0.107 \\
(0.077)\end{array}$ & $\begin{array}{c}0.167 \\
(0.031)\end{array}$ \\
\hline Central & $\begin{array}{c}-0.433 \\
(0.083)\end{array}$ & $\begin{array}{r}-0.416 \\
(0.258)\end{array}$ & $\begin{array}{c}-0.341 \\
(0.119)\end{array}$ & $\begin{array}{c}-0.293 \\
(0.078)\end{array}$ & $\begin{array}{c}0.039 \\
(0.032)\end{array}$ \\
\hline Northeast & $\begin{array}{c}-0.516 \\
(0.087)\end{array}$ & $\begin{array}{r}-0.729 \\
(0.269)\end{array}$ & $\begin{array}{c}-0.389 \\
(0.124)\end{array}$ & $\begin{array}{r}-0.227 \\
(0.089)\end{array}$ & $\begin{array}{c}0.003 \\
(0.033)\end{array}$ \\
\hline $\begin{array}{l}\mathrm{N} \\
\text { Adj. } \mathrm{R}^{2}\end{array}$ & $\begin{array}{c}203 \\
0.326\end{array}$ & $\begin{array}{c}189 \\
0.456\end{array}$ & $\begin{array}{c}189 \\
0.406\end{array}$ & $\begin{array}{c}133 \\
0.354\end{array}$ & $\begin{array}{c}201 \\
0.392\end{array}$ \\
\hline
\end{tabular}

Note: Numbers in Parentheses are standard errors

*: SMSA regression exludes Las Vegas SMSA. 


\section{TABLE V: CITY GROWTH AND UNEMPLOYMENT Dependent Variable: Log of Growth Rate (1960-1990)}

\begin{tabular}{|c|c|c|c|c|c|}
\hline Dependent Variable: & $\begin{array}{c}1 \\
\text { City } \\
\text { Population }\end{array}$ & $\begin{array}{c}2 \\
\text { City } \\
\text { Unem- } \\
\text { ployed } \\
\end{array}$ & $\begin{array}{c}3 \\
\text { City } \\
\text { Employed }\end{array}$ & $\begin{array}{c} \\
\text { City } \\
\text { Population }\end{array}$ & $\begin{array}{c}5 \\
\text { City } \\
\text { Income }\end{array}$ \\
\hline Intercept & 1.777 & 4.544 & 3.787 & 0.963 & 15.944 \\
\hline Log (Population 1960) & $\begin{array}{r}-0.050 \\
(0.024)\end{array}$ & $\begin{array}{c}-0.172 \\
(-0.048)\end{array}$ & $\begin{array}{c}-0.166 \\
(0.045)\end{array}$ & $\begin{array}{c}0.030 \\
(0.025)\end{array}$ & $\begin{array}{l}-0.015 \\
(0.009)\end{array}$ \\
\hline Per Capila Income 1960 ( $\$ 1000)$ & $\begin{array}{r}-0.116 \\
(0.074)\end{array}$ & $\begin{array}{c}-0.354 \\
(0.149)\end{array}$ & $\begin{array}{l}-0.278 \\
(0.141)\end{array}$ & $\begin{array}{c}-0.050 \\
(0.111)\end{array}$ & $\begin{array}{c}-0.084 \\
(0.0297)\end{array}$ \\
\hline Unemployment Rate 1960 & $\begin{array}{r}-0.057 \\
(0.016)\end{array}$ & $\begin{array}{l}-0.164 \\
(0.031)\end{array}$ & $\begin{array}{c}-0.086 \\
(\mathbf{0 . 0 3 0 )}\end{array}$ & $\begin{array}{l}-0.047 \\
(0.017)\end{array}$ & $\begin{array}{c}-0.022 \\
(0.006)\end{array}$ \\
\hline Manufacturing Share 1960 & $\begin{array}{c}-0.631 \\
(0.250)\end{array}$ & $\begin{array}{c}-0.623 \\
(0.490)\end{array}$ & $\begin{array}{l}-1.381 \\
(0.463)\end{array}$ & $\begin{array}{l}-0.888 \\
(0.227)\end{array}$ & $\begin{array}{l}-0.225 \\
(0.095)\end{array}$ \\
\hline \multicolumn{6}{|l|}{ GEOGRAPHICAL DUMMIES } \\
\hline South & $\begin{array}{r}-0.370 \\
(0.085)\end{array}$ & $\begin{array}{l}-0.121 \\
(0.168)\end{array}$ & $\begin{array}{c}-0.243 \\
(0.159)\end{array}$ & $\begin{array}{c}-0.172 \\
(0.079)\end{array}$ & $\begin{array}{c}0.116 \\
(0.033)\end{array}$ \\
\hline Central & $\begin{array}{c}-0.521 \\
(0.084)\end{array}$ & $\begin{array}{l}-0.067 \\
(0.165)\end{array}$ & $\begin{array}{c}-0.269 \\
(0.156)\end{array}$ & $\begin{array}{l}-0.356 \\
(0.079 x\end{array}$ & $\begin{array}{c}0.006 \\
(0.032)\end{array}$ \\
\hline Northeast & $\begin{array}{r}-0.570 \\
(0.086)\end{array}$ & $\begin{array}{c}-0.462 \\
(0.169)\end{array}$ & $\begin{array}{l}-0.321 \\
(0.160)\end{array}$ & $\begin{array}{l}-0.266 \\
(0.160)\end{array}$ & $\begin{array}{c}-0.018 \\
(0.032)\end{array}$ \\
\hline $\begin{array}{l}\mathrm{N} \\
\text { Adj. } \mathrm{R}^{2}\end{array}$ & $\begin{array}{c}203 \\
0.364\end{array}$ & $\begin{array}{c}201 \\
0.268\end{array}$ & $\begin{array}{c}201 \\
0.203\end{array}$ & $\begin{array}{c}133 \\
0.387\end{array}$ & $\begin{array}{c}201 \\
0.426\end{array}$ \\
\hline
\end{tabular}

Note: Numbers in Parentheses are standard errors.

*: SMSA regression exludes Las Vegas SMSA. 
TABLE VI: CITY GROWTH AND EDUCATION Independent Variable: Log of Growth Rate (1960-1990)

\begin{tabular}{|c|c|c|c|c|c|}
\hline Dependent Variable: & $\begin{array}{c}1 \\
\text { City } \\
\text { Popula- } \\
\text { tion }\end{array}$ & $\begin{array}{c}2 \\
\text { City } \\
\text { Popula- } \\
\text { tion }\end{array}$ & $\begin{array}{c}3 \\
\text { City } \\
\text { Popula- } \\
\text { tion }\end{array}$ & $\begin{array}{c}4 \\
\text { SMSA* } \\
\text { Popula- } \\
\text { tion }\end{array}$ & $\begin{array}{c}5 \\
\text { City } \\
\text { Income }\end{array}$ \\
\hline Intercept & 0.819 & -1.108 & 1.104 & 0.422 & 15.664 \\
\hline Log (Population 1960) & $\begin{array}{l}-0.042 \\
(0.024)\end{array}$ & $\begin{array}{c}0.121 \\
(0.248)\end{array}$ & $\begin{array}{l}-0.040 \\
(0.024)\end{array}$ & $\begin{array}{c}0.038 \\
(0.025)\end{array}$ & $\begin{array}{r}-0.012 \\
(0.009)\end{array}$ \\
\hline Per Capita Income 1960 ( $\$ 1000)$ & $\begin{array}{l}-0.212 \\
(0.085)\end{array}$ & $\begin{array}{r}-0.223 \\
(0.087)\end{array}$ & $\begin{array}{l}-0.235 \\
(0.093)\end{array}$ & $\begin{array}{r}-0.177 \\
(0.136)\end{array}$ & $\begin{array}{r}-0.155 \\
(0.034)\end{array}$ \\
\hline Unemployment Rate 1960 & $\begin{array}{c}-0.044 \\
(0.017)\end{array}$ & $\begin{array}{r}-0.044 \\
(0.017)\end{array}$ & $\begin{array}{l}-0.042 \\
(0.017)\end{array}$ & $\begin{array}{r}-0.044 \\
(0.017)\end{array}$ & $\begin{array}{c}-0.018 \\
(0.0065)\end{array}$ \\
\hline Manufacturing Share 1960 & $\begin{array}{l}-0.353 \\
(0.276)\end{array}$ & $\begin{array}{r}-0.322 \\
(0.281)\end{array}$ & $\begin{array}{c}-0.300 \\
(0.284)\end{array}$ & $\begin{array}{r}-0.686 \\
(0.259)\end{array}$ & $\begin{array}{r}-0.144 \\
(0.105)\end{array}$ \\
\hline Median Years of Schooling 1960 & $\begin{array}{c}0.080 \\
(0.035)\end{array}$ & $\begin{array}{c}0.264 \\
(0.280)\end{array}$ & & $\begin{array}{c}0.059 \\
(0.038)\end{array}$ & $\begin{array}{c}0.024 \\
(0.013)\end{array}$ \\
\hline $\begin{array}{l}\text { Median. Schooling in } 1960 \text { times } \\
\text { Log (Population 1960) }\end{array}$ & & $\begin{array}{r}-0.015 \\
(0.023)\end{array}$ & & & \\
\hline $\begin{array}{l}\text { Percent of Population with } \\
12-15 \text { Years of Schooling }\end{array}$ & & & $\begin{array}{c}0.014 \\
(0.006)\end{array}$ & & \\
\hline $\begin{array}{l}\text { Percentage of Population with } \\
16+\text { Years Schooling }\end{array}$ & & & $\begin{array}{c}0.007 \\
(0.008)\end{array}$ & & \\
\hline \multicolumn{6}{|l|}{ GEOGRAPHICAL DUMMIES } \\
\hline South & $\begin{array}{l}-0.309 \\
(0.089)\end{array}$ & $\begin{array}{r}-0.320 \\
(0.090)\end{array}$ & $\begin{array}{l}-0.278 \\
(0.092)\end{array}$ & $\begin{array}{l}-0.152 \\
(0.079)\end{array}$ & $\begin{array}{c}0.133 \\
(0.034)\end{array}$ \\
\hline Central & $\begin{array}{c}-0.489 \\
(0.085)\end{array}$ & $\begin{array}{r}-0.503 \\
(0.088)\end{array}$ & $\begin{array}{l}-0.461 \\
(0.086)\end{array}$ & $\begin{array}{r}-0.353 \\
(0.079)\end{array}$ & $\begin{array}{c}0.016 \\
(0.032)\end{array}$ \\
\hline Northeast & $\begin{array}{l}-0.476 \\
(0.094)\end{array}$ & $\begin{array}{r}-0.490 \\
(0.097)\end{array}$ & $\begin{array}{l}-0.424 \\
(0.101)\end{array}$ & $\begin{array}{r}-0.243 \\
(0.089)\end{array}$ & $\begin{array}{c}0.01 \\
(0.036)\end{array}$ \\
\hline $\begin{array}{l}\mathrm{N} \\
\text { Adj. } \mathrm{R}^{2}\end{array}$ & $\begin{array}{c}203 \\
0.377\end{array}$ & $\begin{array}{c}203 \\
0.375\end{array}$ & $\begin{array}{c}203 \\
0.379\end{array}$ & $\begin{array}{c}133 \\
0.395\end{array}$ & $\begin{array}{c}201 \\
0.432\end{array}$ \\
\hline
\end{tabular}

Note: Numbers in Parentheses are standard errors.

*: SMSA regression exludes Las Vegas SMSA. 
TABLE VII: CITY GROWTH AND EDUCATION FOR TWO SUB-PERIODS Dependent Variable: Log of 20 Year Population Growth rate

\begin{tabular}{|c|c|c|c|c|}
\hline Dependent Variable: & $\begin{array}{c}1 \\
\text { City } \\
(1950-1970)\end{array}$ & $\begin{array}{c}2 \\
\text { City } \\
(1950.1970)\end{array}$ & $\begin{array}{c}3 \\
\text { City } \\
(1970-1990)\end{array}$ & $\begin{array}{c}4 \\
\text { SMSA* } \\
(1970-1990)\end{array}$ \\
\hline Intercept & 1.314 & 1.187 & 0.372 & 0.206 \\
\hline Log (Initial Population) & $\begin{array}{c}-0.073 \\
(0.023)\end{array}$ & $\begin{array}{c}-0.073 \\
(0.023)\end{array}$ & $\begin{array}{r}-0.019 \\
(0.014)\end{array}$ & $\begin{array}{c}-0.021 \\
(0.014)\end{array}$ \\
\hline Median Income $1950(\$ 1000)$ & $\begin{array}{r}-0.034 \\
(0.065)\end{array}$ & $\begin{array}{c}0.038 \\
(0.034)\end{array}$ & & \\
\hline Per Capita Income $1970(\$ 1000)$ & & & $\begin{array}{c}-0.096 \\
(0.033)\end{array}$ & $\begin{array}{c}-0.101 \\
(0.033)\end{array}$ \\
\hline Initial Median Years of Schooling & $\begin{array}{c}0.032 \\
(0.034)\end{array}$ & $\begin{array}{c}0.038 \\
(0.024)\end{array}$ & $\begin{array}{c}0.064 \\
(0.023)\end{array}$ & $\begin{array}{c}0.081 \\
(0.024)\end{array}$ \\
\hline Initial Unemployment Rate & $\begin{array}{c}-1.32 \\
(1.477)\end{array}$ & $\begin{array}{c}-1.797 \\
(1.444)\end{array}$ & $\begin{array}{c}-3.512 \\
(1.182)\end{array}$ & $\begin{array}{r}-0.044 \\
(0.012)\end{array}$ \\
\hline Initial Manufacturing Share & $\begin{array}{r}-0.536 \\
(0.262)\end{array}$ & $\begin{array}{c}-0.493 \\
(0.261)\end{array}$ & $\begin{array}{c}-0.197 \\
(0.172)\end{array}$ & $\begin{array}{c}-0.141 \\
(0.173)\end{array}$ \\
\hline Initial Percent Non-white & $\begin{array}{l}-0.386 \\
(.265)\end{array}$ & & $\begin{array}{c}-0.268 \\
(.106)\end{array}$ & \\
\hline \multicolumn{5}{|l|}{ GEOGRAPHICAL DUMMIES } \\
\hline South & $\begin{array}{c}-0.068 \\
(0.111)\end{array}$ & $\begin{array}{c}-0.128 \\
(0.103)\end{array}$ & $\begin{array}{c}-0.249 \\
(0.06)\end{array}$ & $\begin{array}{c}-0.29 \\
(0.058)\end{array}$ \\
\hline Central & $\begin{array}{c}-0.219 \\
(0.102)\end{array}$ & $\begin{array}{c}-0.24 \\
(0.102)\end{array}$ & $\begin{array}{c}-0.441 \\
(0.054)\end{array}$ & $\begin{array}{c}-0.462 \\
(0.054)\end{array}$ \\
\hline Northeast & $\begin{array}{r}-0.401 \\
(0.096)\end{array}$ & $\begin{array}{c}-0.413 \\
(0.096)\end{array}$ & $\begin{array}{c}-0.38 \\
(0.061)\end{array}$ & $\begin{array}{r}-0.406 \\
(0.061)\end{array}$ \\
\hline $\begin{array}{l}\mathrm{N} \\
\text { Adj. } \mathrm{R}^{2}\end{array}$ & $\begin{array}{c}197 \\
0.351\end{array}$ & $\begin{array}{c}197 \\
0.347\end{array}$ & $\begin{array}{c}202 \\
0.496\end{array}$ & $\begin{array}{c}202 \\
0.482\end{array}$ \\
\hline
\end{tabular}

Note: Numbers in Parentheses are standard errors. 
TABLE VIII: CITY GROWTH AND INEQUALITY

Dependent Variable: Log of Growth Rate (1960-1990)

\begin{tabular}{|c|c|c|c|c|c|}
\hline Dependent Variable: & $\begin{array}{c}1 \\
\text { City } \\
\text { Popula- } \\
\text { tion } \\
\end{array}$ & $\begin{array}{c}2 \\
\text { City } \\
\text { Popula- } \\
\text { tion } \\
\end{array}$ & $\begin{array}{c}3 \\
\text { City } \\
\text { Popula- } \\
\text { tion } \\
\end{array}$ & $\begin{array}{c} \\
\text { SMSA* } \\
\text { Popula- } \\
\text { tion } \\
\end{array}$ & $\begin{array}{c}5 \\
\text { City } \\
\text { Income }\end{array}$ \\
\hline Intercept & 1.007 & -0.083 & 0.854 & -1.458 & 15.871 \\
\hline Log (Population 1960) & $\begin{array}{l}-0.037 \\
(0.025)\end{array}$ & $\begin{array}{r}-0.042 \\
(0.024)\end{array}$ & $\begin{array}{l}-0.045 \\
(0.024)\end{array}$ & $\begin{array}{c}0.024 \\
(0.026)\end{array}$ & $\begin{array}{c}-0.01 \\
(0.009)\end{array}$ \\
\hline Per Capita Income $1960(\$ 1000)$ & $\begin{array}{l}-0.430 \\
(0.158)\end{array}$ & $\begin{array}{r}-0.162 \\
(0.093)\end{array}$ & $\begin{array}{l}-0.314 \\
(0.122)\end{array}$ & $\begin{array}{c}0.437 \\
(0.219)\end{array}$ & $\begin{array}{r}-0.147 \\
(0.037)\end{array}$ \\
\hline Unemployment Rate 1960 & $\begin{array}{l}-0.043 \\
(0.017)\end{array}$ & $\begin{array}{r}-0.046 \\
(0.017)\end{array}$ & $\begin{array}{c}-0.044 \\
(0.0169)\end{array}$ & $\begin{array}{r}-0.043 \\
(0.016)\end{array}$ & $\begin{array}{r}-0.015 \\
(0.007)\end{array}$ \\
\hline Manufacturing Share 1960 & $\begin{array}{l}-0.398 \\
(0.324)\end{array}$ & $\begin{array}{r}-0.359 \\
(0.280)\end{array}$ & $\begin{array}{l}-0.521 \\
(0.312)\end{array}$ & $\begin{array}{r}-0.304 \\
(0.263)\end{array}$ & $\begin{array}{r}-0.107 \\
(0.106)\end{array}$ \\
\hline Median Years of Schooling 1960 & $\begin{array}{c}0.072 \\
(0.039)\end{array}$ & $\begin{array}{c}0.143 \\
(0.047)\end{array}$ & $\begin{array}{c}0.064 \\
(0.038)\end{array}$ & $\begin{array}{c}0.090 \\
(0.037)\end{array}$ & $\begin{array}{c}0.004 \\
(0.018)\end{array}$ \\
\hline $\begin{array}{l}\text { Percent of Population with } \\
\text { Income above } \$ 10,0001960\end{array}$ & $\begin{array}{c}0.016 \\
(0.010)\end{array}$ & & & $\begin{array}{r}-0.007 \\
(0.012)\end{array}$ & \\
\hline $\begin{array}{l}\text { Percent of Population with } \\
\text { Income below } \$ 30001960\end{array}$ & $\begin{array}{c}0.001 \\
(0.007)\end{array}$ & & & $\begin{array}{c}0.026 \\
(0.007)\end{array}$ & \\
\hline $\begin{array}{l}\text { Percent of Population with less } \\
\text { than } 5 \text { Years of Schooling } 1960\end{array}$ & & $\begin{array}{c}0.023 \\
(0.010)\end{array}$ & & & $\begin{array}{l}-0.004 \\
(0.004)\end{array}$ \\
\hline $\begin{array}{l}\text { Percent of Population with more } \\
\text { than } 16 \text { Years of Schooling } 1960\end{array}$ & & $\begin{array}{l}-0.007 \\
(0.009)\end{array}$ & & & $\begin{array}{c}0.007 \\
(0.003)\end{array}$ \\
\hline Mediam Income 1960 & & & $\begin{array}{c}0.007 \\
(0.006)\end{array}$ & & \\
\hline \multicolumn{6}{|l|}{ GEOGRAPHICAL DUMMIES } \\
\hline South & $\begin{array}{l}-0.311 \\
(0.094)\end{array}$ & $\begin{array}{r}-0.350 \\
(0.091)\end{array}$ & $\begin{array}{l}-0.278 \\
(0.093)\end{array}$ & $\begin{array}{r}-0.216 \\
(0.077)\end{array}$ & $\begin{array}{c}0.131 \\
(0.036)\end{array}$ \\
\hline Central & $\begin{array}{l}-0.471 \\
(0.085)\end{array}$ & $\begin{array}{r}-0.447 \\
(0.086)\end{array}$ & $\begin{array}{l}-0.479 \\
(0.085)\end{array}$ & $\begin{array}{c}-0.351 \\
(0.075)\end{array}$ & $\begin{array}{c}0.004 \\
(0.033)\end{array}$ \\
\hline Northeast & $\begin{array}{c}-0.453 \\
(0.095)\end{array}$ & $\begin{array}{l}-0.462 \\
(0.094)\end{array}$ & $\begin{array}{c}-0.460 \\
(0.095)\end{array}$ & $\begin{array}{c}-0.214 \\
(0.085)\end{array}$ & $\begin{array}{c}0.002 \\
(0.036)\end{array}$ \\
\hline $\begin{array}{l}\mathrm{N} \\
\text { Adj. } \mathrm{R}^{2}\end{array}$ & $\begin{array}{c}203 \\
0.379\end{array}$ & $\begin{array}{c}203 \\
0.386\end{array}$ & $\begin{array}{c}203 \\
0.378\end{array}$ & $\begin{array}{c}133 \\
0.460\end{array}$ & $\begin{array}{c}201 \\
0.439\end{array}$ \\
\hline
\end{tabular}

Note: Numbers in Parentheses are standard errors.

*: SMSA regression exludes Las Vegas SMSA. 
TABLE IX: CITY GROWTH AND RACE

Dependent Variable: Log of Growth Rate (1960-1990)

\begin{tabular}{|c|c|c|c|c|c|}
\hline Dependent Variable: & $\begin{array}{c}1 \\
\text { City } \\
\text { Popula- } \\
\text { tion } \\
\end{array}$ & $\begin{array}{c}2 \\
\text { City } \\
\text { Popula- } \\
\text { tion } \\
\end{array}$ & $\begin{array}{c}3 \\
\text { City } \\
\text { Popula- } \\
\text { tion } \\
\end{array}$ & $\begin{array}{c}4 \\
\text { SMSA* } \\
\text { Popula. } \\
\text { tion } \\
\end{array}$ & $\begin{array}{c}5 \\
\text { City } \\
\text { Income }\end{array}$ \\
\hline Intercept & 0.908 & 0.938 & 1.481 & 0.355 & 15.627 \\
\hline Log (Population 1960) & $\begin{array}{l}-0.043 \\
(0.025)\end{array}$ & $\begin{array}{r}-0.042 \\
(0.024)\end{array}$ & $\begin{array}{l}-0.043 \\
(0.024)\end{array}$ & $\begin{array}{c}0.033 \\
(0.027)\end{array}$ & $\begin{array}{r}-0.012 \\
(0.009)\end{array}$ \\
\hline Per Capita Income $1960(\$ 1000)$ & $\begin{array}{c}0.043 \\
(0.067)\end{array}$ & $\begin{array}{c}-0.202 \\
(0.086)\end{array}$ & $\begin{array}{l}-0.159 \\
(0.088)\end{array}$ & $\begin{array}{r}-0.146 \\
(0.146)\end{array}$ & $\begin{array}{r}-0.117 \\
(0.035)\end{array}$ \\
\hline Percent Non-white 1960 & $\begin{array}{l}-0.005 \\
(0.002)\end{array}$ & $\begin{array}{r}-0.002 \\
(0.002)\end{array}$ & $\begin{array}{l}-0.048 \\
(0.025)\end{array}$ & $\begin{array}{c}0.002 \\
(0.003)\end{array}$ & $\begin{array}{l}0.001 \\
(0.001)\end{array}$ \\
\hline Unemployment Rate 1960 & & $\begin{array}{r}-0.043 \\
(0.017)\end{array}$ & $\begin{array}{l}-0.039 \\
(0.017)\end{array}$ & $\begin{array}{r}-0.043 \\
(0.017)\end{array}$ & $\begin{array}{r}-0.019 \\
(0.007)\end{array}$ \\
\hline Manufacturing Share 1960 & & $\begin{array}{r}-0.402 \\
(0.285)\end{array}$ & $\begin{array}{l}-0.429 \\
(0.284)\end{array}$ & $\begin{array}{l}-0.653 \\
(0.265)\end{array}$ & $\begin{array}{l}-0.128 \\
(0.108)\end{array}$ \\
\hline Median Years of Schooling 1960 & & $\begin{array}{c}0.070 \\
(0.038)\end{array}$ & $\begin{array}{c}0.060 \\
(0.038)\end{array}$ & $\begin{array}{c}0.061 \\
(0.038)\end{array}$ & $\begin{array}{c}0.027 \\
(0.014)\end{array}$ \\
\hline Segregation Index 1960 & & & $\begin{array}{l}-0.006 \\
(0.006)\end{array}$ & & \\
\hline $\begin{array}{l}\text { Segregation Index times Percent } \\
\text { Non-white } 1960\end{array}$ & & & $\begin{array}{c}0.529 \\
(0.284)\end{array}$ & & \\
\hline \multicolumn{6}{|l|}{ GEOGRAPHICAL DUMMIES } \\
\hline South & $\begin{array}{l}-0.150 \\
(0.085)\end{array}$ & $\begin{array}{l}-0.289 \\
(0.093)\end{array}$ & $\begin{array}{l}-0.296 \\
(0.103)\end{array}$ & $\begin{array}{l}-0.162 \\
(0.081)\end{array}$ & $\begin{array}{c}0.127 \\
(0.036)\end{array}$ \\
\hline Central & $\begin{array}{l}-0.517 \\
(0.078)\end{array}$ & $\begin{array}{l}-0.483 \\
(0.085)\end{array}$ & $\begin{array}{l}-0.482 \\
(0.092)\end{array}$ & $\begin{array}{r}-0.358 \\
(0.079)\end{array}$ & $\begin{array}{c}0.014 \\
(0.033)\end{array}$ \\
\hline Northeast & $\begin{array}{l}-0.602 \\
(0.082)\end{array}$ & $\begin{array}{l}-0.479 \\
(0.094)\end{array}$ & $\begin{array}{l}-0.478 \\
(0.094)\end{array}$ & $\begin{array}{r}-0.242 \\
(0.089)\end{array}$ & $\begin{array}{c}0.01 \\
(0.036)\end{array}$ \\
\hline $\begin{array}{l}N \\
\text { Adi. } R^{2}\end{array}$ & $\begin{array}{c}203 \\
0.308\end{array}$ & $\begin{array}{c}203 \\
0.375\end{array}$ & $\begin{array}{c}203 \\
0.381\end{array}$ & $\begin{array}{c}133 \\
0.392\end{array}$ & $\begin{array}{c}201 \\
0.431\end{array}$ \\
\hline
\end{tabular}

Note: Numbers in Parentheses are standard errors.

*: SMSA regression exludes Las Vegas SMSA. 
TABLE X: CITY GROWTH AND GOVERNMENT EXPENDITURE

Dependent Variable: Log of City Growth Rate (1960-1990)

\begin{tabular}{|c|c|c|c|c|c|}
\hline Dependent Variable & $\begin{array}{c}\text { City } \\
\text { Popula- } \\
\text { tion } \\
\end{array}$ & $\begin{array}{c}\text { City } \\
\text { Popula- } \\
\text { tion }\end{array}$ & $\begin{array}{c}\text { City } \\
\text { Popula- } \\
\text { tion }\end{array}$ & $\begin{array}{c}\text { City } \\
\text { Popula- } \\
\text { tion }\end{array}$ & $\begin{array}{l}\text { City } \\
\text { Income }\end{array}$ \\
\hline Intercept & 0.803 & 0.734 & 0.771 & 0.812 & 15.66 \\
\hline Log (Population 1960) & $\begin{array}{l}-0.047 \\
(0.025)\end{array}$ & $\begin{array}{r}-0.056 \\
(0.025)\end{array}$ & $\begin{array}{l}-0.048 \\
(0.025)\end{array}$ & $\begin{array}{r}-0.042 \\
(0.025)\end{array}$ & $\begin{array}{r}-0.018 \\
(0.01)\end{array}$ \\
\hline Per Capita Income 1960 ( $\$ 1000)$ & $\begin{array}{l}-0.225 \\
(0.087)\end{array}$ & $\begin{array}{r}-0.183 \\
(0.091)\end{array}$ & $\begin{array}{l}-0.229 \\
(0.086)\end{array}$ & $\begin{array}{r}-0.216 \\
(0.087)\end{array}$ & $\begin{array}{r}-0.125 \\
(0.034)\end{array}$ \\
\hline Median Years of Schooling 1960 & $\begin{array}{c}0.085 \\
(0.036)\end{array}$ & $\begin{array}{c}0.081 \\
(0.036)\end{array}$ & $\begin{array}{c}0.088 \\
(0.036)\end{array}$ & $\begin{array}{c}0.077 \\
(0.038)\end{array}$ & $\begin{array}{c}0.029 \\
(0.014)\end{array}$ \\
\hline Unemployment Rate 1960 & $\begin{array}{l}-0.044 \\
(0.017)\end{array}$ & $\begin{array}{r}-0.035 \\
(0.017)\end{array}$ & $\begin{array}{l}-0.043 \\
(0.017)\end{array}$ & $\begin{array}{r}-0.044 \\
(0.017)\end{array}$ & $\begin{array}{r}-0.018 \\
(0.006)\end{array}$ \\
\hline Manufacturing Share 1960 & $\begin{array}{l}-0.340 \\
(0.277)\end{array}$ & $\begin{array}{r}-0.366 \\
(0.283)\end{array}$ & $\begin{array}{l}-0.344 \\
(0.277)\end{array}$ & $\begin{array}{l}-0.413 \\
(0.277)\end{array}$ & $\begin{array}{l}-0.13 \\
(0.104)\end{array}$ \\
\hline Per Capita Revenue 1960 & $\begin{array}{c}0.290 \\
(0.392)\end{array}$ & $\begin{array}{r}-0.492 \\
(0.501)\end{array}$ & & & \\
\hline Property Revenue Share 1960 & & $\begin{array}{c}0.137 \\
(0.163)\end{array}$ & & & \\
\hline $\begin{array}{l}\text { Intergovernmental Revenue Share } \\
1960\end{array}$ & & $\begin{array}{c}0.202 \\
(0.235)\end{array}$ & & & \\
\hline Per Capita Debt 1960 & & $\begin{array}{c}0.462 \\
(0.175)\end{array}$ & & & \\
\hline Per Capita Expenditure 1960 & & & $\begin{array}{c}0.408 \\
(0.370)\end{array}$ & $\begin{array}{c}0.445 \\
(0.466)\end{array}$ & $\begin{array}{c}0.297 \\
(0.156)\end{array}$ \\
\hline Police Share of Expenditure 1960 & & & & $\begin{array}{r}-0.504 \\
(0.678)\end{array}$ & \\
\hline $\begin{array}{l}\text { Highway Share of Expenditure } \\
1960\end{array}$ & & & & $\begin{array}{r}-0.003 \\
(0.388)\end{array}$ & \\
\hline $\begin{array}{l}\text { Sanitation Share of Expenditure } \\
1960\end{array}$ & & & & $\begin{array}{l}0.557 \\
(0.294)\end{array}$ & \\
\hline \multicolumn{6}{|l|}{ GEOGRAPHICAL DUMMIES } \\
\hline South & $\begin{array}{c}-0.305 \\
(0.089)\end{array}$ & $\begin{array}{r}-0.325 \\
(0.089)\end{array}$ & $\begin{array}{c}-0.303 \\
(0.089)\end{array}$ & $\begin{array}{c}-0.329 \\
(0.095)\end{array}$ & $\begin{array}{c}0.13 \\
(0.034)\end{array}$ \\
\hline Central & $\begin{array}{l}-0.482 \\
(0.085)\end{array}$ & $\begin{array}{r}-0.486 \\
(0.085)\end{array}$ & $\begin{array}{l}-0.475 \\
(0.085)\end{array}$ & $\begin{array}{c}-0.492 \\
(0.090)\end{array}$ & $\begin{array}{c}0.018 \\
(0.032)\end{array}$ \\
\hline Northeast & $\begin{array}{l}-0.483 \\
(0.095) \\
\end{array}$ & $\begin{array}{r}-0.485 \\
(0.104) \\
\end{array}$ & $\begin{array}{l}-0.481 \\
(0.094) \\
\end{array}$ & $\begin{array}{c}-0.481 \\
(0.097) \\
\end{array}$ & $\begin{array}{l}-0.008 \\
(0.037)\end{array}$ \\
\hline $\begin{array}{l}\mathrm{N} \\
\text { Adj. } \mathrm{R}^{2}\end{array}$ & $\begin{array}{c}203 \\
0.375\end{array}$ & $\begin{array}{c}203 \\
0.389\end{array}$ & $\begin{array}{c}203 \\
0.378\end{array}$ & $\begin{array}{c}201 \\
0.378\end{array}$ & $\begin{array}{l}201 \\
0.44\end{array}$ \\
\hline
\end{tabular}

Note: Numbers in Parentheses are standard errors. 